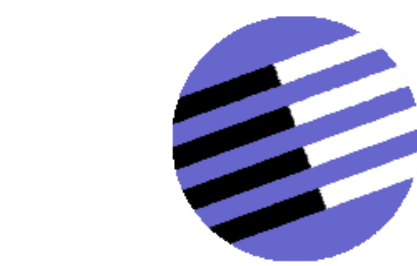

GOVERNANCE AND THE EFFICIENCY

OF ECONOMIC SYSTEMS

CESY

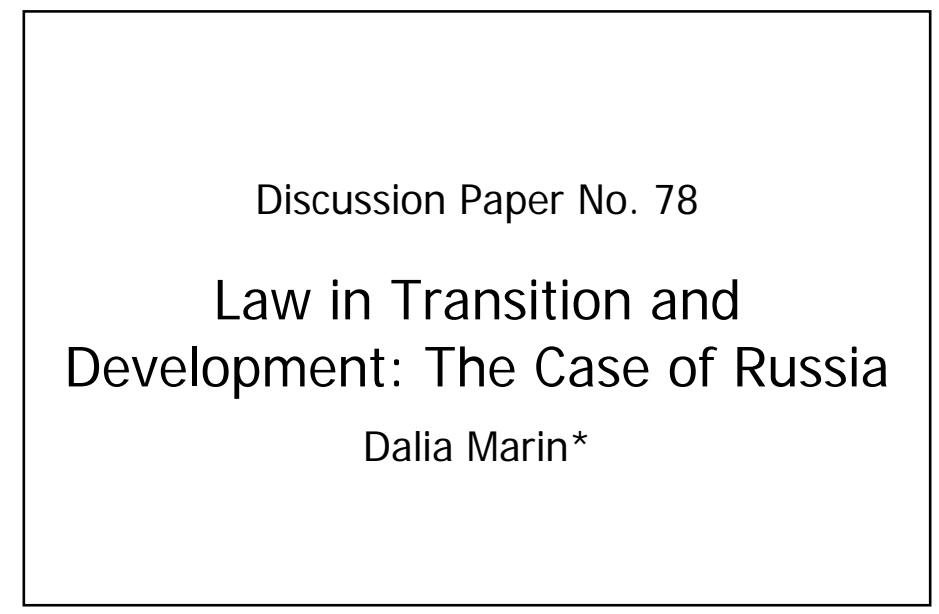

April 2004

*Dalia Marin, University of Munich and CEPR

Financial support from the Deutsche Forschungsgemeinschaft through SFB/TR 15 is gratefully acknowledged. 


\title{
Law in Transition and Development: The Case of Russia ${ }^{*}$
}

\author{
Dalia Marin, University of Munich and CEPR
}

April 2004

\begin{abstract}
The rise of barter and non-cash payments has become a dominant feature of the Russian transition to a market economy. This paper confronts with empirical evidence two approaches to explain barter in Russia: the 'illusion view' and the 'trust view' of barter. The 'illusion view' suggests that barter allows the parties to pretend that the manufacturing sector in Russia is producing value added by enabling this sector to sell its output at a higher price than its market value. The 'trust view' sees barter as an institution to deal with the absence of trust and liquidity in the Russian economy. We confront the prediction of both explanations with actual data on barter in Ukraine in 1997. The data reject the 'illusion view' in favor of the "trust view' of barter.
\end{abstract}

JEL Classification: D20, G30, O10, P30

Keywords: imperfect input and capital markets, the virtual economy, trade credit, trust, contract enforcement

*Acknowledgment: Financial support from the Deutsche Forschungsgemeinschaft through SFB/TR 15 is gratefully acknowledged. 


\section{Introduction}

Demonetization has become one of the dominant features of the Russian transition to a market economy. Different estimates suggest that the share of non-cash payments made 60 percent of sales in 1998 in Russia and 50 percent of sales in Ukraine in 1997. ${ }^{1}$ The survey of 200 firms by the Russian Economic Barometer since 1992, in turn, suggests that non-cash payments rose steadily from 8 percent in 1992 to 54 percent in mid-1998. Since the financial crisis in August of 1998 barter and other money surrogates have started to decline accounting for less than 10 percent of receipts of industrial firms in February 2003. A similar picture emerges from a Goskomstat survey among 2000 large firms which reveals a share of non-cash payments of around 70 percent in early 1998 and a subsequent decline to 60 percent in 1999.

Figure 1. Barter Share of Total transactions in Russia 1992 - 2003

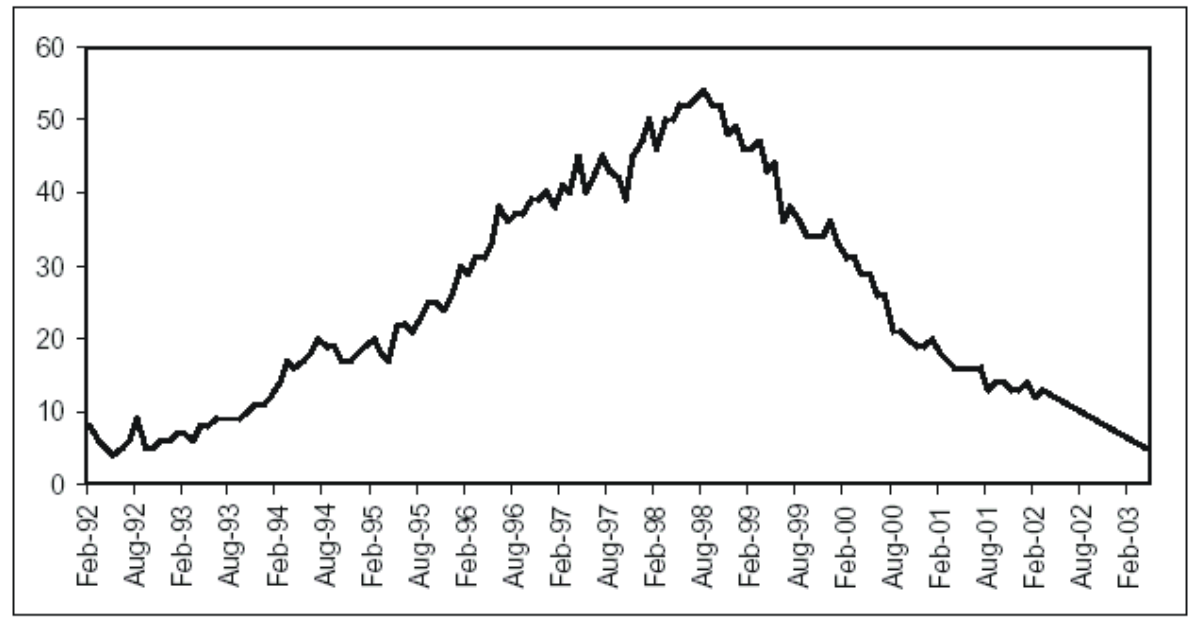

Source: Russian Economic Barometer

\footnotetext{
${ }^{1}$ See Commander and Mummsen 1998 for Russia, Marin, Kaufmann, Gorochowskij 2000 for Ukraine.
} 
This time pattern of the process of demonetization is particularly puzzling. Barter started to rise after macroeconomic stabilization and has started to decline when macroeconomic instability set in after the August financial crisis. How can this time pattern of demonetization in the Russian economy be explained?

In this paper I look at the empirical validity of one of the most influential explanations of demonetization in Russia - the virtual economy argument. ${ }^{2}$ The argument claims that by allowing to change the prices of the goods exchanged in a hidden way barter helps different groups in the economy to keep the illusion that the manufacturing sector is producing valuable output while in fact it is not. Based on a unique deal-specific data set of 165 barter deals in Ukraine in 1997 we have information on the price differential between the cash and barter prices for the individual goods exchanged in barter deals. Thus, we can put the virtual economy argument to an empirical test. We find that illusion is not what is driving the actual pricing behavior in barter deals. We then proceed to offer a stylized model of how the observed pricing behavior in barter deals can be explained. The model sees the non-cash economy as an institutional response to the lack of trust and liquidity in the Russian economy. We test the price predictions of the model with actual price data and find that the data do not reject the trust view of the non-cash economy.

Why does it matter whether the "illusion-view" or the "trust-view" is better able to describe the actual development in Russia? The two views differ with respect to their policy implications of how to remonetize the Russian economy. If the "illusion-view" is correct, the main source of the problem lies in the real sector of the economy and barter is a "bad" thing because it allows the manufacturing sector to avoid restructuring and thus to avoid to get rid of the distortions in the real sector. If the "trust-view" is the correct description, then the main source of the problem lies in the financial sector of the economy and barter is a "good" thing because it allows the real sector to finance production when the banking sector does not fulfill its role of intermediation to channel private savings to finance investment in the real sector. According to both views barter helps to maintain production. The "illusion view" sees barter to help maintain an inefficient output

\footnotetext{
${ }^{2}$ See Gaddy and Ickes 1998, for the empirical validity of other explanations, see Marin, Kaufmann, and Gorochowskij 2000.
} 
by pretending that it is valuable. The "trust view" sees barter to help maintain a valuable output by overcoming a financial and input shortage which otherwise would lead to the collapse of output.

In a final section the paper concludes by discussing how a model based on trust can explain the evolution of barter over time in Russia and by discussing what has contributed to the vanishing barter economy after the August 1998 financial crisis in Russia.

By looking at how a model based on trust can explain the shift in the terms of trade of the non-cash economy in the former Soviet Union, this paper complements previous work on the subject. In Marin and Schnitzer (2003) we focus on the ouput decline in transition economies and we show how a model based on trust and liquidity can explain why the economic performance of the former Soviet Union was much worse than that of Central Europe. In Marin, Kaufmann, Gorochowskij (2000) we expose to the data several of the explanations of barter in transition economies which have been given in the literature like soft-budget constraints, market distortions, tax avoidance, and the lack of credit. Finally, in Huang, Marin, $\mathrm{Xu}$ (2003) we examine possible long-term costs of barter by focusing on the banking failure. We explore how barter may have contributed to a banking development trap which hinders the sector to fulfil its role as a financial institution in Russia.

\section{Some Stylized Facts}

We conducted a survey among 55 enterprises in Ukraine in 1997 from three cities Kyiv (50 percent), Zaporioshje (30 percent), and Dnipropetrovsk (20 percent). From this survey we obtained deal-specific information on 165 barter deals. Each barter deal includes information on the selling firm and the buying firm and the type of goods exchanged. We distinguish the "sale" side of the barter deal and the "goods payment". The interviewed firms were selected from an address list of firms of the local office of the Harvard Institute of Internationale Development in Kyiv. These firms were contacted by phone in order to secure their cooperation. The 55 firms of our sample were finally those who agreed to participate in the survey. The unit of analysis of the survey was one particular barter deal. Each firm provided us with information on 3 deals. The questionnaire asked for information 
on about forty dimensions on the "sale" and the "goods payment" side of the barter transaction. The "sale" was defined by the transaction of the seller who initiated the deal. The "goods payment" was the buyer's payment for the "sale". Because of the length of the questionnaire we personally visited these firms to fill in the questionnaire. Many of the firms were well informed about the firms they traded with because these firms served as financiers. This is how we obtained firm level information for about 100 firms (depending on the respective information) by interviewing 55 firms. The average share of barter in percent of firms' sales is 45 percent with a minimum barter share of 1 percent and a maximum share of 100 percent. The barter deals are typically large in size ranging between US $\$$ 10 and US\$ 5,000,000 with a mean size of US\$ 135,679. Firms' arrears make on average 30 percent of firms' sales with a maximum of 626 percent. On average, firms financed 6.31 percent of output by bank debt with a maximum of over 100 percent.

Table 1 identifies the type of firms involved in barter deals. The table illustrates that the non- cash economy is not an exclusive phenomenon of state owned enterprises. In 29.7 percent of the deals the selling firm is a state enterprise and in 20.6 percent a private firm. 4.2 percent of the sample consist of barter deals with workers. On the buying end of the barter transaction the picture looks similar. In 29.5 percent of the deals the buying firm is a state owned enterprise and in 25.2 percent of the deals a private firm. ${ }^{3}$

\footnotetext{
${ }^{3}$ The firms in the address list were selected to secure representativity of the data material. Attention has been paid in particular to having a good representation of sectors, firm sizes, and ownership structure of firms compared to the Ukrainian economy. An ex-post comparison of the data sample with available aggregate data indicates that the data are indeed fairly representative.
} 


\begin{tabular}{lcc}
\hline & $\begin{array}{c}\text { selling firm } \\
\text { in percent }\end{array}$ & $\begin{array}{c}\text { buying firm } \\
\text { in percent }\end{array}$ \\
\hline domestic state or state controlled enterprise & 29,70 & 29,45 \\
domestic private firm & 20,61 & 25,15 \\
foreign firm & 0,0 & 2,45 \\
leaseholder/ cooperative & 1,82 & 4,29 \\
worker & 4,24 & 0,0 \\
the government & 0,0 & 4,29 \\
collective owned enterprise & 33,94 & 29,45 \\
GUS firm & 4,24 & 4,29 \\
joint-venture & 5,45 & 0,61 \\
\hline total & & 100,00 \\
\hline
\end{tabular}

Source: Survey of 165 barter deals in Ukraine in 1997

Table 2 looks at the sectoral pattern of these 165 barter deals. Two things appear from the table. First, there is not much difference in the sectoral pattern between the "sale" side of the barter transaction and the "goods payment" side. Second, barter dominates in food and beverages, in the basic sector, and in machinery and vehicles. 


\begin{tabular}{lcc}
\hline & $\begin{array}{c}\text { "sale" } \\
\text { in percent }\end{array}$ & $\begin{array}{c}\text { "goods payment" } \\
\text { in percent }\end{array}$ \\
\hline natural resources & 28,48 & 30,30 \\
textile \& leather & 7,88 & 5,45 \\
wood \& paper & 2,42 & 4,24 \\
machinery \& vehicles & 16,97 & 23,03 \\
food \& beverages & 16,36 & 22,42 \\
chemicals & 13,33 & 9,09 \\
services & 14,55 & 0,61 \\
others & 0,0 & 4,85 \\
\hline total & 100,00 & 100,00 \\
\hline
\end{tabular}

Source: Survey of 165 barter deals in Ukraine in 1997

Table 3 gives the terms of trade effect of the non-cash economy. From our survey data we have information on the percentage price difference between the barter price and the cash price for each of the 165 barter deals of the sample. We have this information for both sides - the "sale" and the "goods payment" of each deal so that we can calculate the net terms of trade effect of barter. SCASH is the percentage price difference between the barter price and the cash price on the "sale" side of the barter deal. PCASH is the percentage difference between the barter price and the cash price on the "goods payment" of the barter deal. TOT measures the net terms of trade of barter and is calculated by TOT $=$ SCASH PCASH. ${ }^{4}$ It appears from the table that on the "sale" side of the deal the prices charged in barter are inflated by up to $50 \%$ compared to cash deals. This happened in $23.3 \%$ of the cases while in $73.6 \%$ of the deals there was no difference between the two prices charged. In $3.1 \%$ of the cases the firms involved discounted

\footnotetext{
${ }^{4}$ We obtained this information from the following question. "What is the percentage price difference between the price you charge/you are charged for this particular good in this barter deal as compared to the typical price you charge/you are charged for the same product in cash deals?"
} 
the price on the "sale" by up to $17 \%$. In order to calculate who benefits from demonetization one has to look also at the pricing behavior on the "goods payment" side of the deal. Here it appears that in 25.9 percent of the cases the firms discounted the price for the barter good compared to what they typically charge in cash deals by as much as $50 \%$. In $62.9 \%$ of the deals there was no discounting or inflating on the barter prices for the goods payment. In $11.1 \%$ of the deals the barter prices were inflated by as much as $200 \%$. Because of these differences in the pricing behavior between barter and cash deals, the net terms of trade effect of barter appears to be quite substantial ranging between $-200 \%$ and $50 \%$. As a result the non-cash economy appears to lead to a substantial shift in the terms of trade compared to the cash-economy. In almost 45 percent of the deals barter shifts the terms of trade towards the "sale" side of the transaction. In those cases the "real" barter price of the "sale" is inflated by up to $50 \%$ compared to the cash price for the same goods.

What explains this shift in the terms of trade of the non-cash economy? Why does barter lead to an increase of the real price for the "sale"? Who benefits from this shift and who loses? In the next two sections we look at two possible explanations for this shift in the terms of trade. 


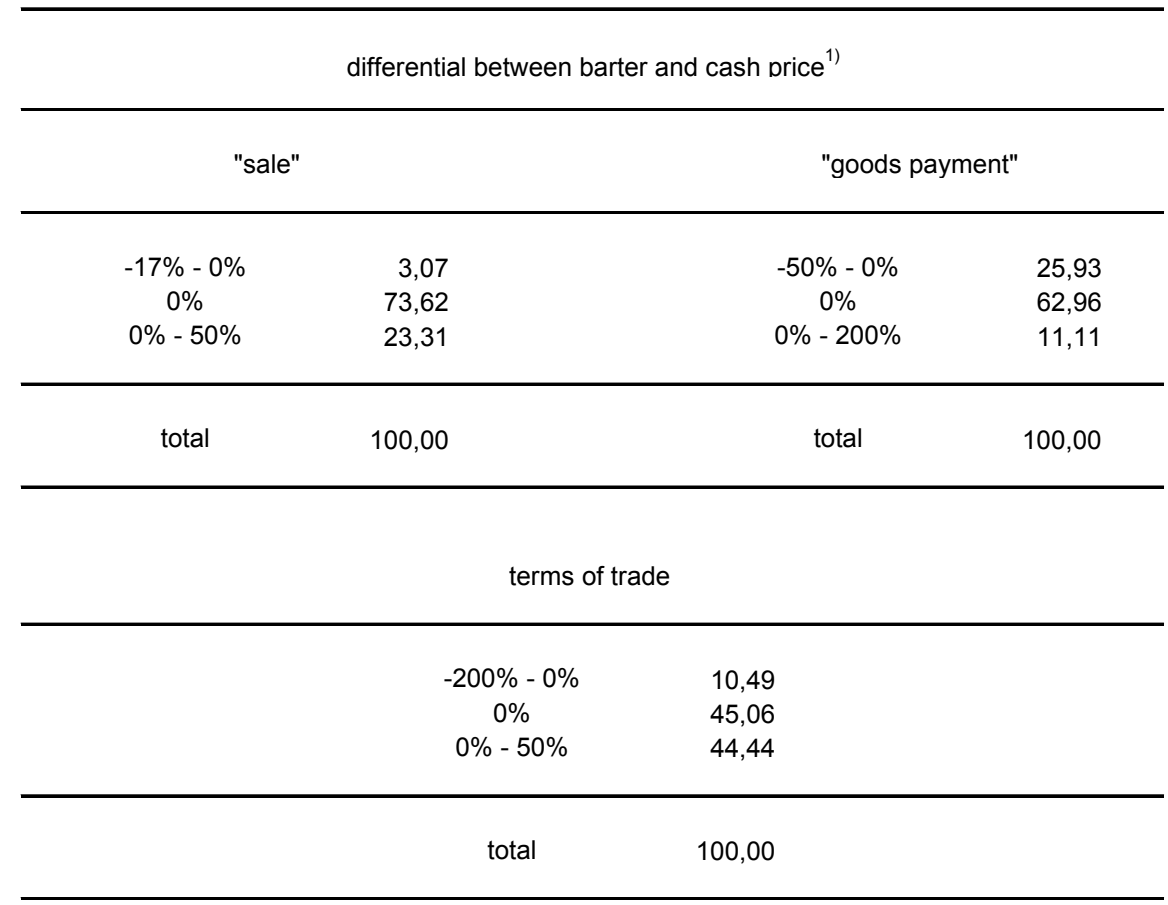

Source: Survey of 165 barter deals in Ukraine in 1997

1) in percent of cash price

\section{3. "Illusion" and the Non-Cash Economy}

The virtual economy argument of Gaddy and Ickes (1998) rests on the assumption that the manufacturing sector does not produce valuable output and important groups in the economy (like the government and firms in different sectors) have an interest to pretend that this is not the case. According to this argument barter - a payment in goods or money surrogates rather than cash - is a way for these participants to keep the illusion of a value-creating manufacturing sector by allowing the latter sector to sell its output at a higher price than its market value and the value-adding natural resource sector to accept this overpricing out of lack of other opportunities. This way the manufacturing sector survives by drawing resources from the natural resource sector. According to the argument, keeping up the illusion of a value-adding manufacturing sector is highly costly for the Russian economy at large because this cross-subsidizing from the value-adding natural resource sector to the value-subtracting manufacturing sector prevents 
the manufacturing sector from moving into valuable activity. But if the natural resource sector is producing valuable output, why has the sector nothing better to do than to subsidize the manufacturing sector? In fact, the natural resource sector is supposed to have significant bargaining power in the interaction with other sectors when it is producing goods which the market values highly. Why then does the sector end up subsidizing the rest of the economy? The argument does not make much economic sense. However, the argument appeals to experts of central planning and policy observers in transition economies, because the practice of cross-subsidizing across different activities in the economy was a widespread feature of central planning. Therefore, let us pretend for a moment that the virtual economy argument does make economic sense and let us see whether it is actually true.

We can answer this question from our survey data, since we have information on the percentage price difference between the barter and cash prices for each of the 165 barter deals in the sample. We have this information for both sides (the "sale" and the "goods payment") of each barter deal so that we can calculate to whose favor the terms of trade shifts in non-cash transactions. As Table 3 illustrates the terms of trade shifts quite substantially in non-cash transactions. Thus, the virtual economy argument has the potential of explaining some of the variation in the terms of trade of barter. ${ }^{5}$

If the virtual economy argument is valid, we expect that the manufacturing sector (like textiles, leather, machinery, and vehicles) is overpricing its output in barter compared to cash deals for the same product and pays less than the market value for natural resources (like gas and electricity). Furthermore, we expect this pricing distortion to be more pronounced for less efficient sectors.

In order to test these hypotheses we have to distinguish whether the sector is on the buying or selling end of the barter transaction. The reason is that overpricing the "sale" will benefit the sector which is on the selling end of the barter transaction and hurt the sector which is on the buying end of the same transaction. Similarly, discounting the price for the "goods payment" will benefit the sector which is on the buying end and hurt the sector which is on the selling end. TOT measures the net terms of trade and is calculated by TOT $=$ SCASH

\footnotetext{
${ }^{5}$ The data are from Ukraine and not from Russia. Both countries are, however, very similar with respect the macroeconomic situation as well as the development of their legal and financial institutions.
} 
- PCASH. Thus, when the sector is on the selling end and TOT takes a positive value, barter benefits this sector by shifting the terms of trade in its favor. Similarly, when the sector is on the buying end and TOT takes a positive value, then barter hurts this sector by shifting the terms of trade in its disfavor.

We are now ready to put the virtual economy argument to an empirical test. Table 4 examines whether differences in the pricing behavior across sectors can be identified. The table aggregates the 165 barter deals into 4 sectors and looks at their pricing behavior in non-cash deals compared to cash deals. The table distinguishes whether the sector is on the selling or buying end of the transaction. From Table 4 it appears that there is no systematic difference in the pricing behavior across sectors in non-cash transactions (the F-test of the Analysis of Variance (Anova) is not statistically significant at conventional levels). Take the example of the manufacturing sector which includes textiles, leather, machinery and vehicles, and chemicals. When this sector is on the selling end of the transaction, it overprices its output on average by 4.03 percent compared to cash deals and it is discounted on the goods payment by 0.75 percent on average, so that the sector's net benefit from barter is 4.78 percent (in terms of its cash price). ${ }^{6}$ So far so good. But the same appears to be true for the natural resource sector which includes electricity and gas, coke, petroleum, metal ores and non-metallic minerals. This sector's net benefit from barter is 4.88 percent (in terms of its cash price). What seems to matter here for the pricing behavior in non-cash transactions is not the sector, but whether the sector is on the selling or buying end of the transaction. Take again the example of the manufacturing sector. When this sector is on the buying end of the barter deal, it pays more for the "sale" by 4.81 percent on average and sells its "good payment" at a 3.52 percent discount compared to cash deals, so that the sector's net loss from barter is 8.33 percent on average. This net loss from non-cash transactions appears to be happening in all the other sectors as well, when the sector is a buyer rather than a seller. It appears then that the sectors gain from barter when they sell and they loose from barter when they buy. This is not what we would have expected if we believed in the virtual economy argument of Russia's non-cash economy.

\footnotetext{
${ }^{6}$ The average percent price differential between barter and cash appear to be low from table 4. These averages hide the actual variation in the price differentials, because in 45 percent of the deals the non-cash and cash prices were equal. For the distribution of the price differentials see Table 3 .
} 
Table 4

Pricing Behavior of Sectors

\begin{tabular}{|c|c|c|c|c|c|c|c|}
\hline & & \multicolumn{3}{|c|}{ selling sector } & \multicolumn{3}{|c|}{ buying sector } \\
\hline & & $\operatorname{scash}^{1)}$ & pcash $^{2)}$ & $\operatorname{tot}^{3)}$ & scash & pcash & tot \\
\hline \multirow{3}{*}{ electricity \& gas } & mean & 0,00 & $-4,12$ & 4,12 & 3,78 & 7,42 & $-3,64$ \\
\hline & std. dev. & 0,00 & 8,52 & 8,52 & 8,80 & 45,06 & 42,11 \\
\hline & $\mathrm{N}$ & 17 & 17 & 17 & 18 & 18 & 18 \\
\hline \multirow{3}{*}{ coke \& petroleum } & mean & 5,48 & 1,45 & 4,03 & 1,13 & $-1,31$ & 2,44 \\
\hline & std. dev. & 14,45 & 10,28 & 8,37 & 5,50 & 6,54 & 6,57 \\
\hline & $\mathrm{N}$ & 13 & 13 & 13 & 16 & 16 & 16 \\
\hline \multirow{3}{*}{$\begin{array}{l}\text { metal ores \& other non- } \\
\text { metallic minerals }\end{array}$} & mean & 5,00 & $-1,29$ & 6,29 & 2,50 & 0,58 & 1,92 \\
\hline & std. dev. & 10,16 & 6,05 & 10,05 & 8,09 & 17,02 & 18,29 \\
\hline & $\mathrm{N}$ & 17 & 17 & 17 & 18 & 18 & 18 \\
\hline \multirow{3}{*}{ food \& beverages } & mean & 2,64 & 1,00 & 1,64 & 3,03 & $-2,47$ & 5,51 \\
\hline & std. dev. & 6,53 & 38,45 & 35,75 & 9,45 & 15,38 & 14,09 \\
\hline & $\mathrm{N}$ & 27 & 27 & 27 & 36 & 36 & 36 \\
\hline \multirow{3}{*}{ textiles \& leather } & mean & 1,86 & 0,26 & 1,61 & 5,21 & $-4,17$ & 9,38 \\
\hline & std. dev. & 8,46 & 6,86 & 9,99 & 7,11 & 7,93 & 9,66 \\
\hline & $N$ & 16 & 16 & 16 & 12 & 12 & 12 \\
\hline \multirow{3}{*}{ machinery \& vehicles } & mean & 3,66 & 0,91 & 2,75 & 3,46 & $-5,06$ & 8,52 \\
\hline & std. dev. & 7,41 & 10,64 & 13,51 & 7,67 & 9,96 & 11,40 \\
\hline & $\mathrm{N}$ & 28 & 28 & 28 & 30 & 30 & 30 \\
\hline \multirow{3}{*}{ chemicals } & mean & 6,08 & $-3,60$ & 9,68 & 7,19 & 0,07 & 7,12 \\
\hline & std. dev. & 9,49 & 12,50 & 11,18 & 9,47 & 12,01 & 8,59 \\
\hline & $\mathrm{N}$ & 22 & 22 & 22 & 15 & 15 & 15 \\
\hline \multirow{3}{*}{ services } & mean & 2,83 & $-4,04$ & 6,86 & 0,00 & $-10,00$ & 10,00 \\
\hline & std. dev. & 6,54 & 17,72 & 16,27 & , & , & , \\
\hline & $\mathrm{N}$ & 23 & 23 & 23 & 1 & 1 & 1 \\
\hline \multirow{3}{*}{ total } & mean & 3,43 & $-1,16$ & 4,59 & 3,52 & $-1,21$ & 4,73 \\
\hline & std. dev. & 8,30 & 18,63 & 18,07 & 8,26 & 19,66 & 18,86 \\
\hline & $\mathrm{N}$ & 163 & 163 & 163 & 146 & 146 & 146 \\
\hline \multirow[t]{2}{*}{ Anova } & F-test & 1,08 & 0,33 & 0,52 & 0,76 & 0,77 & 0,93 \\
\hline & sign. level & $(0,382)$ & $(0,937)$ & $(0,817)$ & $(0,619)$ & $(0,614)$ & $(0,489)$ \\
\hline
\end{tabular}

We now examine whether this result depends on the level of aggregation of sectors. In Table 5 we aggregate the sectors to a natural resource sector (includ- 
ing electricity and gas, coke and petroleum, metal ores and other non-metallic minerals) and to a manufacturing sector (including textiles, leather, machinery, vehicles, and chemicals). We construct a variable which we call virtual economy 1 which includes all deals in which the natural resource sector was on the selling end of the transaction and the manufacturing sector on the buying end. If the virtual economy argument is valid then we expect to see a discount on the "sale" price and a mark-up over the cash price on the "goods payment" leading to a net terms of trade shift in favor of the manufacturing sector. A look at Table 5 reveals that the opposite is the case. The natural resource sector lives at the expense of the manufacturing sector who suffers a loss in the terms of trade of 6.88 percent on average when the natural resource sector is the seller and manufacturing the buyer in the transaction. Can the manufacturing sector draw on the resources of the natural resource sector when he is selling to this sector rather than buying from it? This case is captured by the variable virtual economy 2 which includes all deals in which manufacturing is the seller and the natural resources sector the buyer in the transaction. The table reveals that in this case both sectors are overpricing their output in non-cash transactions compared to cash leading to a slight terms of trade gain for the manufacturing sector of 1.13 percent. Moreover, the constellation of the manufacturing sector as the seller and the natural resource sector as the buyer in barter has been taking place in 23 deals only out of a total of 165 deals. These numbers are much too small to plausibly explain the enormous shift towards non-cash transactions in Russia. Furthermore, the F-tests reject the hypothesis that there is any difference in the pricing behavior for both constellations.

We turn now to the second prediction of the virtual economy argument. The bottom part of Table 5 examines whether the price distortions between noncash and cash deals are more pronounced for less efficient firms. If the virtual economy argument is valid we expect this to be the case, because firms with lower productivity will need to inflate their prices by more or get bigger discounts for the barter goods in order to pretend to produce value added. From the table it appears that there is no statistical significant relation between the price distortions and the efficiency of the firm. If at all, it appears to be the firms with productivity levels in the middle range who show the largest price differentials between non-cash and cash transactions. ${ }^{7}$

\footnotetext{
${ }^{7}$ Moreover, Marin, Kaufmann, Gorochowskij (2000) show that the firm's barter exposure does not increase for less efficient firms.
} 
Table 5

Is Russia's Economy Virtual ?

$\%$ price differential on

\begin{tabular}{|c|c|c|c|c|c|c|c|}
\hline & \multicolumn{2}{|c|}{ "sale" 1) } & \multicolumn{2}{|c|}{ "goods payment" 2) } & \multicolumn{2}{|c|}{ "terms of trade" ${ }^{3)}$} & \multirow[b]{2}{*}{$\mathrm{N}$} \\
\hline & mean & std. dev. & mean & std. dev. & mean & std. dev. & \\
\hline \multicolumn{8}{|l|}{ virtual economy 1} \\
\hline $\begin{array}{l}\text { seller: natural resources } \\
{ }^{4)} \\
\text { buver: manufacturina }{ }^{5}\end{array}$ & 1,47 & 4,24 & $-5,41$ & 9,24 & 6,88 & 9,30 & 17 \\
\hline other & 3,66 & 8,63 & $-0,66$ & 19,39 & 4,32 & 18,84 & 146 \\
\hline total & 3,43 & 8,30 & $-1,16$ & 18,63 & 4,59 & 18,07 & 163 \\
\hline Anova F-test & & 1,06 & & 0,99 & & 0,31 & \\
\hline sign. level & & $(0,306)$ & & $(0,321)$ & & $(0,581)$ & \\
\hline \multicolumn{8}{|l|}{ virtual economy 2} \\
\hline $\begin{array}{l}\text { seller: manufacturing } \\
\text { buyer: natural resources }\end{array}$ & 1,43 & 5,85 & 0,30 & 12,91 & 1,13 & 14,20 & 23 \\
\hline other & 3,76 & 8,61 & $-1,40$ & 19,44 & 5,15 & 18,62 & 140 \\
\hline total & 3,43 & 8,30 & $-1,16$ & 18,63 & 4,59 & 18,07 & 163 \\
\hline Anova F-test & & 1,55 & & 0,16 & & 0,98 & \\
\hline sign. level & & $(0,215)$ & & $(0,686)$ & & $(0,324)$ & \\
\hline \multicolumn{8}{|l|}{ firm's efficiency ${ }^{6}$} \\
\hline low & 3,13 & 7,78 & $-0,13$ & 11,21 & 3,27 & 12,26 & 57 \\
\hline medium & 2,76 & 7,07 & $-4,88$ & 10,60 & 7,64 & 12,24 & 60 \\
\hline high & 2,91 & 10,11 & 1,16 & 33,96 & 1,75 & 31,29 & 36 \\
\hline total & 2,93 & 8,08 & $-1,69$ & 19,03 & 4,62 & 18,58 & 153 \\
\hline Anova F-test & & 0,03 & & 1,45 & & 1,38 & \\
\hline sign. level & & $(0,969)$ & & $(0,239)$ & & $(0,255)$ & \\
\hline
\end{tabular}

1) difference between the barter price and the cash price in percent of cash price in the "sale" side of the barter deal, denoted scash.

${ }^{2)}$ difference between the barter price and the cash price in percent of cash price in the "goods payment" of the barter deal, denoted pcash.

${ }^{3)}$ terms of trade $=$ scash - pcash

${ }^{4)}$ includes electricity \& gas, coke \& petroleum and metal ores \& other non- metallic minerals.

${ }^{5)}$ includes textiles \& leather, mashinery \& vehicles, and chemicals.

${ }^{6)}$ output per employee. Low : 1,000 to 7,500 US $\$$, medium: 7,100 to 15,000 US $\$$, high: 15,100 to 140,000 US $\$$. 
In Table 6 we look at the distribution of the terms of trade of barter for two leading sectors: manufacturing and electricity \& gas. The first three columns of the table give the pricing behavior of electricity \& gas when the sector is on the selling end of the transaction. It can be seen from the table that the sector charges the same price as in cash deals when it sells electricity \& gas and receives in more than 20 percent of the deals a discount of up to $50 \%$ for the goods he is paid with so that the terms of trade shifts in more than $20 \%$ of the deals in favor of the electricity \& gas sector. The table shows no single case in which this sector has been subsidizing an other sector when doing a barter deal. The next three columns of the table look at the pricing behavior of electricity \& gas when this sector is on the buying end of the transaction. In this case the sector buys in more than $16 \%$ of the deals an overpriced good from other sectors (the price is inflated by up to 50\%) and gives a discount on electricity and gas of up to $50 \%$ when selling it to other sectors so that the sector ends up with a terms of trade loss of up to $50 \%$ in $33 \%$ of the deals. When this terms of trade loss of the electricity \& gas sector is compared to the terms of trade loss of the manufacturing sector as a buyer (as can be seen in the last column of the same table) the latter sector has to suffer a loss in $53.6 \%$ of the deals (compared to $33 \%$ of electricity \& gas).

To conclude, the virtual economy argument is virtual and has no basis in the data. Who benefits from the non-cash economy does not depend on the sector, as the argument claims, but is exclusively driven by the selling or buying status of firms. But why would the selling or buying status of firms determine in who's favor the terms of trade shifts in barter? Or to put it differently, why are frequently prices for the "sale" inflated and prices for the "goods payment" discounted in barter transactions? I turn to an answer to this question in the next section. ${ }^{8}$

${ }^{8}$ The fact that the terms of trade is shifting in $45 \%$ of the deals towards the "sale" side of the barter deal casts further doubts on the explanation that barter is driven by tax motives. As Table 3 shows it is only in $10.5 \%$ of the deals in which firms could potentially hide some of their profits lowering their tax base. This number corresponds roughly to the number of cases in which the interviewed firms gave taxes some importance for undertaking a barter deal, see Marin, Kaufmann, Gorochowskij (2000). 


\begin{tabular}{|c|c|c|c|c|c|c|}
\hline \multirow[t]{3}{*}{ Table 6} & \multicolumn{6}{|c|}{$\begin{array}{c}\text { Terms of Trade } \\
\text { in percent }\end{array}$} \\
\hline & \multicolumn{3}{|c|}{$\begin{array}{c}\text { seller } \\
\text { gas \& electricity }\end{array}$} & \multicolumn{3}{|c|}{$\begin{array}{c}\text { buyer } \\
\text { gas \& electricity }\end{array}$} \\
\hline & scash & pcash & tot & scash & pcash & tot \\
\hline$<0 \%$ & 0,0 & 23,53 & 0,0 & 0,0 & 22,22 & 5,56 \\
\hline $0 \%$ & 100,00 & 76,47 & 76,47 & 83,33 & 72,22 & 61,11 \\
\hline$>0 \%$ & 0,0 & 0,0 & 23,53 & 16,67 & 5,56 & 33,33 \\
\hline missing & 0,0 & 0,0 & 0,0 & 0,0 & 0,0 & 0,0 \\
\hline \multirow[t]{3}{*}{ total } & 100,00 & 100,00 & 100,00 & 100,00 & 100,00 & 100,00 \\
\hline & \multicolumn{3}{|c|}{$\begin{array}{c}\text { seller } \\
\text { manufacturing }\end{array}$} & \multicolumn{3}{|c|}{$\begin{array}{c}\text { buyer } \\
\text { manufacturing }\end{array}$} \\
\hline & scash & pcash & tot & scash & pcash & tot \\
\hline$<0 \%$ & 4,48 & 20,90 & 10,45 & 1,45 & 26,09 & 5,80 \\
\hline $0 \%$ & 62,69 & 68,66 & 40,30 & 66,67 & 63,77 & 39,13 \\
\hline$>0 \%$ & 31,34 & 8,96 & 47,76 & 31,88 & 8,70 & 53,62 \\
\hline missing & 1,49 & 1,49 & 1,49 & 0,0 & 1,45 & 1,45 \\
\hline total & 100,00 & 100,00 & 100,00 & 100,00 & 100,00 & 100,00 \\
\hline
\end{tabular}

Source: Survey of 165 barter deals in Ukraine in 1997

1) manufactoring: textiles \& leather, wood \& paper, machinery \& vehicles, and chemicals

\section{4. "Trust" and the Non-Cash Economy}

If the virtual economy argument has no empirical basis, how can we explain that the seller is overpricing the "sale" and the buyer is discounting the price for the "goods payment" in non-cash transactions? If hiding a valueless output is not the reason, what else motivates such pricing behavior? We turn now to a model for an answer. 


\subsection{A Stylized Model ${ }^{9}$}

Consider a good which requires $n$ steps of production to become a final good. Each production step is carried out by a different firm. After $n$ steps of refinement the intermediate good becomes a final good. Each buyer along the chain can negotiate only with his supplier. This leads to $n$ bargaining problems along the chain. At each of these steps we assume Nash bargaining with both parties equally sharing the joint surplus. The value of the surplus is denoted by $v>0$. Intermediate goods are assumed to have zero value when sold outside the production chain.

Lets looks at the first production chain in more detail. Consider a supplier of the original input good, $S_{1}$, and the buyer $B_{1}$. We assume that $B_{1}$ makes a relationship specific investment $i$ at date 0.9. This investment can be thought of as the time and money $B_{1}$ spends in order to find an adequate supplier. At the time of this investment, the two firms are assumed not to be able to write a contract which commits $S_{1}$ to deliver the input good for a particular price in the future. Thus, $B_{1}$ must first invest and only then - when the investment costs are sunk- can bargain over the input price. This leads to a hold up problem in the bargaining of the price when the input good is actually delivered.

At date 1, the two parties can negotiate about the delivery of $S_{1}$ 's input good and about the price. $\mathrm{v}_{1}$ denotes the value of the input good to $B_{1}$. We assume that $B_{1}$ cannot pay cash at the time of delivery of the input good because he is liquidity constraint. Thus, $S_{1}$ has to deliver the input good on a credit basis, if at all. $B_{1}$ will be able to pay when he is paid $v_{1}$ by the next firm in the production chain. We assume that enforcing credit repayment to be difficult in transition economies and thus $S_{1}$ has to incur some fixed cost $x$ to enforce repayment of $p_{1}$. This cost could be thought of as the cost of using the courts and lawyers fees and potential bribes for judges or other public officials or the cost of private enforcement like the use of Mafia etc ${ }^{10}$.

\footnotetext{
${ }^{9}$ This section follows Marin and Schnitzer (2003).

${ }^{10}$ The literature on contract enforcement in Eastern Europe suggests that enforcement with the help of legal institutions is possible but costly see Hendley, Murrell and Ryterman (1999); Johnson, McMillan and Woodruff (1999) get a similar result from their survey among five transition countries that legal institutions do matter and are used although relational contracting dominates.
} 
At date 1.1 after delivery of the input good $B_{1}$ can try to default on some of his payment. Let $\tilde{p}_{1}$ denote the price paid by $B_{1}$ at this date. Figure 2 summarizes the time sequence of the bargaining at production step 1.

Figure 2: Bargaining at the production step 1

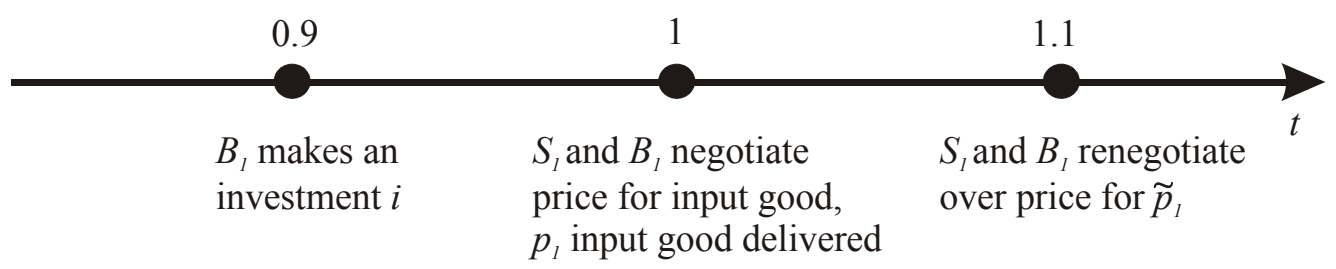

Let us solve production step 1 recursively. Recall that at date 1 , when $S_{1}$ delivers the input good, $B_{1}$ has no cash to pay for the input. Thus, once the input supplier delivers the input, the bargaining power reverses and shifts to $B_{1}$. Now the input supplier has to worry of being paid. At date 1.1, after realizing his profits from selling the input to the next firm, $B_{1}$ has enough cash to pay but if he does not do so voluntarily $S_{1}$ has to incur cost $x$ to enforce payment of $p_{1}$. Suppose $B_{1}$ holds up now the input supplier and refuses to pay the full price $p_{1}$ on which the two parties agreed at date 1 , but offers to pay $\tilde{p}_{1}=p_{1}-x$ instead. If this happens, $S_{1}$ can either accept this payment or enforce $p_{1}$ at cost $x$. In equilibrium he will accept $B_{1}$ 's reduced payment.

At date 1 , the two parties have to agree on a price $p_{1}$. Since $B_{1}$ 's investment $i$ is already sunk at this date, it is not taken into account in the bargaining over the input price. Thus, $B_{1}$ might not invest in finding a supplier relationship because these costs are not covered by the price. This is what constitutes the hold up problem of buyer $B_{1}$. However, the two parties anticipate at date 1 that $B_{1}$ will exploit his position after delivery of the input good and pay a reduced price at date 1.1. Assuming Nash bargaining whenever possible this implies that a price $p_{1}$ is chosen such that

$$
v_{1}-\left(p_{1}-x\right)=p_{1}-x \leftrightarrow p_{1}=\frac{v_{1}}{2}+x
$$

i.e., in anticipation of $B_{1}$ 's future price reduction, $S_{1}$ marks up $p_{1}$ in the first place, if this is possible. 
However, inflating the input price in anticipation of the price reduction at date 1.1 will not always be possible. $B_{1}$ 's liquidity constraint - the cash he gets when he himself sells the good to the next buyer, i.e. $v_{1}$ - puts an upper bound on the maximum payment that can be enforced at cost $x$. Thus, in order to fully capture the subsequent price reduction $S_{1}$ may want to inflate the price by more than can credibly be enforced as payment at date 1.1, since even at cost $x, B_{1}$ cannot be forced to pay more than he has in his pockets at date 1.1. Thus,

$$
p_{1}=\min \left(\frac{v_{1}}{2}+x ; v_{1}\right)
$$

If $x$ is sufficiently large, i.e. $x>v_{1} / 2, B_{1}$ 's liquidity constraint becomes binding which will make it impossible for $S_{1}$ to pass on these costs to him. $B_{1}$ 's cash from the sale to the next firm will simply not be enough to fully cover these costs. In this case, $B_{1}$ can exploit the fact that he is liquidity constrained to prevent to be held up by the input supplier. This will, however, only work when enforcement $\operatorname{costs} x$ are just right. When $x$ is low, i.e. $x<v_{1} / 2$, then $S_{1}$ is able to pass on $x$ in the price mark-up. In this case, the buyer's liquidity constraint does not prevent an equal sharing of the surplus. When $x$ becomes too large, i.e. $x>v_{1}$, then $B_{1}$ captures the entire surplus and $S_{1}$ cannot guarantee himself a positive payoff. Thus, in order for the liquidity constraint to alleviate $B_{1}$ 's hold-up problem we have

$$
\frac{v_{1}}{2}<i \leq x<v_{1}
$$

Without a liquidity constraint and enforcement costs, $B_{1}$ 's payoff would be $v_{1} / 2$, i.e. half the value of production at the first production step, and if $i>v_{1} / 2$ then no production would take place at all, because the surplus does not cover $B_{1}$ 's investment costs $i$. However, if enforcement costs are sufficiently high, $B_{1}$ can exploit this fact to capture more than one half of the production value. Thus, $B_{1}$ 's ex-post bargaining power has to be sufficiently large to cover his ex-ante investment, i.e. $i \leq x$ in order for production to take place. Since $S_{1}$ needs a positive profit in order to participate in the deal, enforcement costs may not be too high either; i.e. $x<v_{1}$.

We have just seen that $S_{1}$ may not be willing to deliver the input good if the credit problem is too severe, i.e. if $x>v_{1}$. Thus, if the buyer has no cash and the legal system to enforce payment is poorly developed a potentially valuable transaction does not take place. Can barter - a trade credit in goods rather than 
cash - help under these circumstances?

Suppose $B_{1}$ can produce one unit of a barter good, but only after date 1 . Let $w$ denote the value of the barter good and let $k$ denote $B_{1}$ 's production cost. If $B_{1}$ sells this barter good to someone outside the production chain he does so at a cash price $p^{c}=(w+k) / 2$, assuming again Nash bargaining. This would give $B_{1}$ a payoff of $(w-k) / 2$. However, $B_{1}$ can also use this barter good as a collateral to improve his creditworthiness. In this case, $B_{1}$ promises to deliver the barter good to $S_{1}$ when credit repayment is due. The price for this barter good, $p^{B}$, is fixed together with $p_{1}$ before $S_{1}$ decides about his input delivery. The two parties negotiate prices $p_{1}$ and $p^{B}$ such that they split the surplus of both transactions equally, taking into account the renegotiation on $p_{1}$ at date 1.1. This means that the inclusion of the barter trade allows $B_{1}$ to shift some profit back to $S_{1}$ by discounting the price of the barter good $p^{B}$. Note, however, that $p^{B}$ cannot be chosen arbitrarily small because $B_{1}$ cannot be forced to deliver the barter good as promised, but has to be induced to do so voluntarily. If $B_{1}$ cheats on $S_{1}$ and refuses to deliver, all $S_{1}$ can do, given that $B_{1}$ has signed a contract that promises delivery of the barter good, is to try to prevent a sale of the barter good to someone else. We assume that $S_{1}$ suceeds with such an attempt with probability $(1-\pi)$ which reduces $B_{1}$ 's potential payoff from selling the barter good to $\pi(w-k) / 2$, where $\pi<1$. This effectively means that barter creates a hostage of a given size $\mathrm{z}$, where

$$
z=(1-\pi) \frac{(w-k)}{2}
$$

Note first, that the size of the hostage $z$ created by barter depends on two things. First, the value of the hostage increases with the value of the good offered as a means of payment in barter. This is given by the payoff $(w-k) / 2$ when the good is sold independently of barter. Second, the value of the hostage declines with $B_{1}$ 's cheating payoff when he defaults on payment which is expressed by $\pi(w-$ $k) / 2$. The difference between these two payoffs is determined by the parameter $\pi$ and captures the commitment value which $B_{1}$ achieves by agreeing to repay the trade credit in goods rather than cash. By doing so, $B_{1}$ reduces his chances to sell the barter good to someone else than $S_{1}$. $(1-\pi)$ is the probability of being caught when $B_{1}$ cheats on repayment and sells the barter good to someone else than $S_{1}$. The parameter $\pi$ can be thought of as a measure of how well the input seller can label the barter good as his property. The smaller $\pi$, the less "anonymous" 
the means of payment and the smaller $B_{1}$ 's cheating surplus from defaulting on payment. Thus, the smaller $\pi$, the larger the commitment value of barter and the larger the hostage z. $B_{1}$ uses the barter contract as a commitment not to exploit his bargaining power and to shift some profit back to $S_{1}$ in order to make him participate in the deal when his profit from the input transaction is too low due to large credit enforcement cost $x$. In this sense, barter creates a deal-specific collateral that helps to alleviate the hold-up problem when credit enforcement is prohibitively costly. ${ }^{11}$

What does the model imply for the pricing behavior in barter transactions? We need to evaluate how the hold-up problem and the credit problem just described will be reflected in the terms of the barter contract. We have just argued that the hold-up problem in the input deal can be alleviated if the input buyer faces a credit constraint and barter is used if credit enforcement becomes too costly for the input seller. Thus, we expect this problems to be reflected in the prices chosen in non-cash transactions as compared to prices in cash deals where no such problems are present.

Recall from equation (2) that the price for the input good in barter is

$$
p_{1}=\min \left(\frac{v_{1}}{2}+x ; v_{1}\right)
$$

Compare this price with the cash price for the same input with no such problems. Without the hold-up problem the price for the input will reflect the fact that $B_{1}$ has undertaken an investment, because in this case the investment cost $i$ can be contracted on before $B_{1}$ 's investment takes place. Furthermore, the input price will not reflect the credit enforcement cost $x$, because in this case $B_{1}$ has no liquidity constraint and thus there are no enforcement costs $x$. Splitting the surplus implies a cash price $p_{1}^{c}$

$$
p_{1}^{c}=\frac{\left(v_{1}-i\right)}{2}
$$

Comparing (5) and (6) shows that within barter the price for the "sale" side of the deal will be inflated compared to the cash price for the same input, because the cash price will take into account $B_{1}$ 's investment cost $i$ (because there is no

\footnotetext{
${ }^{11}$ Kranton (1996) suggests that barter as a form of reciprocal exchange can be quite costly by locking trading partner in.
} 
hold up problem) and will not include a mark-up for the credit enforcement cost $x$ (because there is no credit problem).

If $p_{1}$ cannot be increased anymore because it reaches its upper bound $v_{1}$, then we expect the price for the "goods payment" to be discounted. When the liquidity constraint is binding and thus $S_{1}$ cannot inflate the price for the "sale", barter allows $B_{1}$ to shift some of the profit back to $S_{1}$ by giving a discount on the "goods payment". Thus, we expect that the hold-up problem and the credit problem both shift the terms of trade in favor of the input supplier, either by an increase of $p_{1}$ as compared to $p_{1}^{c}$ or when this is not possible by a decrease of $p^{B}$ as compared to the cash price for the barter good or both. 


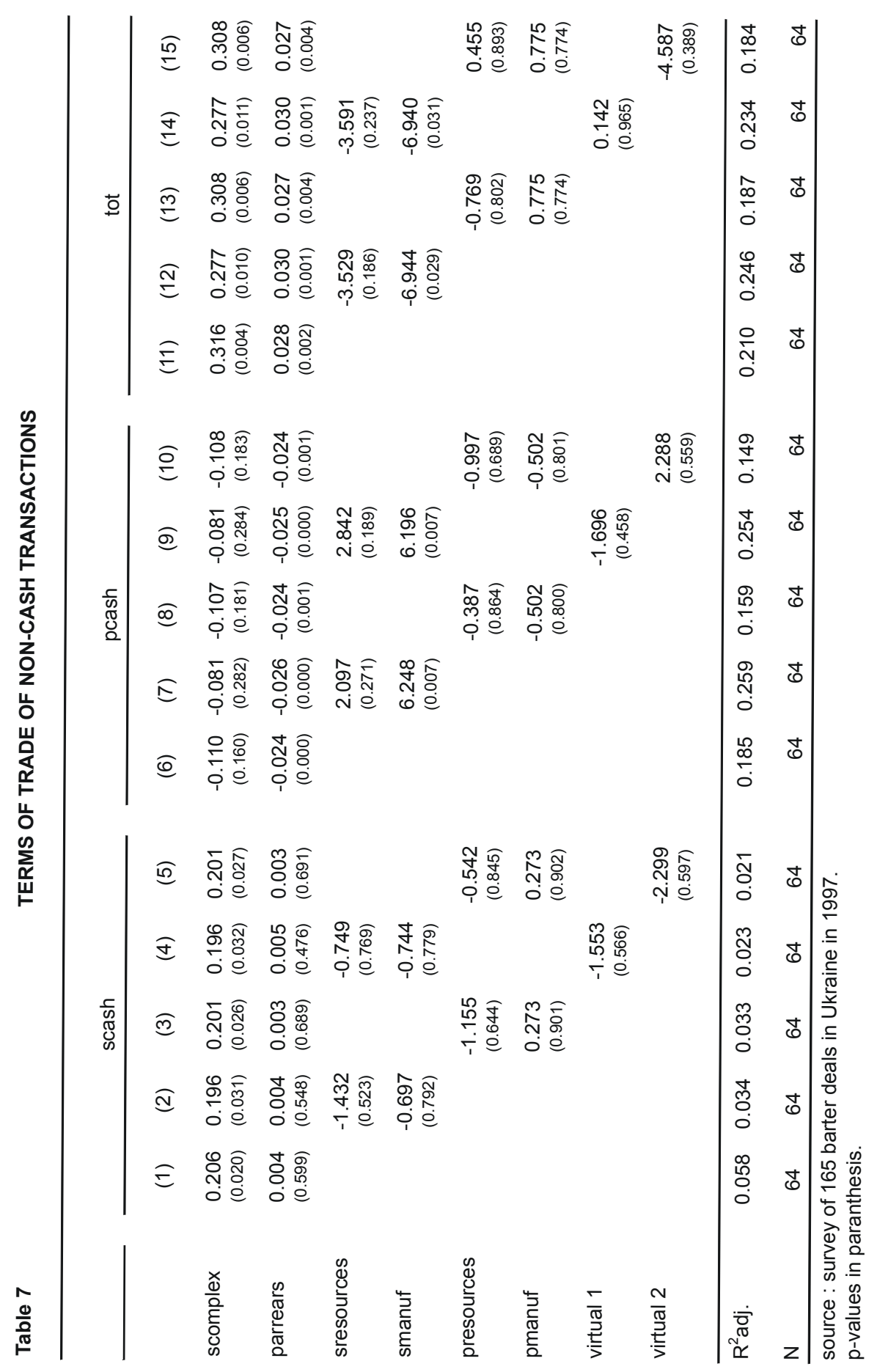




\subsection{Empirical Evidence}

We are now ready to put the model to an empirical test to see whether the incentive problems just described can indeed explain some of the observed pricing behavior in non-cash transactions.

For the regression analysis we will use SCASH, PCASH, and TOT as the indepentent variables. Recall that TOT is defined as the difference of SCASH and PCASH, where SCASH and PCASH are the percentage differences between the barter price and the cash price for the input good (the "sale") and the barter good (the "goods payment"), respectively. First, we have to find proxies for the incentive problems described in the previous section. We measure the severety of the hold up problem on the input good by the complexity index suggested by Blanchard and Kremer 1997. We construct a deal-specific complexity measure for the input good SCOMPLEX. SCOMPLEX is an index that takes the value of zero if the "sale" is produced with one input only and approaches one when the "sale" good uses several inputs from other sectors. The number of inputs required for the "sale" good to be produced stands here for the number of bargaining problems $B_{1}$ faces. We matched the ISIC sectors of the "sale" good with the sector of the complexity index given by Blanchard and Kremer 1997. We use as a measure for the credit problem (a measure for $x$ ) the input buyer's $B_{1}$ outstanding firm arrears PARREARS. The idea is that the more $B_{1}$ is indebted already the less likely it is that he will repay the trade credit and thus the lower his creditworthyness.

Table 7 shows the regressions explaining SCASH, PCASH, and TOT with these two incentive problems. The more complex the "sale" good the more severe is the hold-up problem in the input deal and thus the larger the barter price $p_{1}$ relative to the cash price $p_{1}^{c}$. Thus, we expect a positive sign on the complexity variable SCOMPLEX in the SCASH regressions (given in columns 1 - 5 of the table). ${ }^{12}$ We have no prediction for SCOMPLEX in the PCASH regressions (given in columns 6 - 10 of the table). Because of the positive effect of SCOMPLEX on SCASH we expect also a positive sign for SCOMPLEX in the TOT regressions (given in columns 11 - 15). This is supported by the results of the table. The input specific complexity measure is positive and significant in all the SCASH

\footnotetext{
${ }^{12}$ Note that the estimated coefficient on the complexity index can be used to test whether the hold up problem is on the buyer's or on the seller's side. A positive coefficient indicates that the buyer is held up by the seller rather than the other way around.
} 
and TOT regressions. Thus, the "real" prices for the "sale" appears to be inflated because of the presence of a hold-up problem in the input deal.

Turning to the credit problem we expect PARREARS to have a positive effect on SCASH, since $S_{1}$ will inflate the barter price for the input $p_{1}$ relative to the cash price $p_{1}^{c}$ to cover the anticipated credit enforcement costs $x$. Furthermore, we expect a negative sign for the PARREARS variable in the regressions for PCASH, since barter is undertaken to shift some of the profit back to the supplier by discounting the price for the barter good. Because of these effects on barter prices on both sides of the transaction, we expect PARREARS to have a positive effect on TOT. Turning to the results, we see that PARREARS is insignificant in the SCASH regressions which suggests that the supplier is not able to pass on the credit enforcement costs to the buyer. PARREARS turns out to be highly significant and negative in the PCASH regressions. These results for the PARREARS variable in the SCASH and PCASH regressions support the story given by the model of the previous section. Barter is needed to save the deal exactly when the supplier is unable to pass on the enforcement costs to the buyer and as a result does not expect to have a positive profit from the transaction. Discounting the price for the barter good is then a way to make the deal go through by shifting back part of the profit to the supplier. This explains why the prices for the "goods payment" are predominantly discounted compared to cash prices for the same goods.

Finally, we include several sectoral dummies (smanuf, pmanuf, sresources, presources, virtual1 virtual2) to test whether those have any explanatory power for the pricing behavior in non-cash transactions. None of these variables are significant at conventional levels except for the variable SMANUF in the PCASH and TOT regressions. The positive and significant sign of the estimated coefficient for SMANUF in the PCASH regressions and its negative and significant effect in the TOT regressions suggests, however, that the manufacturing sector suffers losses in the terms of trade by being overpriced on the "goods payment" even when the sector is a seller in barter transactions. Thus, the manufacturing sector is the only sector that appears to never gain from non-cash transactions. This is just the opposite of what the virtual economy argument suggests. Note that this finding of the regression analysis is somewhat not consistent with the results in Table 4 of section 3 in which the manufacturing sector as a seller gains from barter. A closer look at Table 4 reveals, however, that the manufacturing sector like textiles, leather, machinery, vehicles is gaining the least as a seller in barter transactions 
compared to the rest of the economy. For example, the sectors textiles and leather are gaining 1.6 percent on average as a seller compared to a gain of 6.3 percent of metal ores and of 4.6 percent when all selling sectors are aggregated (given in the bottom of Table 4). These averages hide the distribution of the mark-ups on the "sale" which the regression analysis takes into account. This is the reason why Table 4 gives a small gain for manufacturing as a selling sector while the regression analysis indicates a loss from barter for this case.

\section{Conclusion}

In this paper I explore an influential explanation for the non-cash economy in Russia, the virtual economy argument, based on deal-specific price data of 165 barter deals in Ukraine. I find that the argument is not consistent with the actual pricing behavior in barter deals. First, there appears to be no statistically significant difference in the pricing behavior across sectors. Second, the only sector which appears to suffer a loss from the non-cash economy is the manufacturing sector.

I then proceed to offer a model based on the lack of trust and liquidity. The pricing predictions from this model are then put to an empirical test. It turns out that real prices on the "sale" side of the barter transaction are inflated, because they reflect a trust problem and a credit problem between input suppliers and producing firms. Input suppliers are exploiting the fact that there are only a few suppliers around and thus switching suppliers is costly and charge higher prices for their inputs in barter deals compared to cash deals (this is how the trust problem materializes). If this price mark-up for inputs would happen in cash deals firms would refuse to buy those expensive inputs and prefer not to produce. Furthermore, input suppliers have to incur costs of enforcing payment (they have to involve the Mafia or legal firms) which they want to be covered by the deal. If these credit enforcement costs become very large (which happens when legal institutions do not work properly or when firms are already very indebted) then input suppliers will refuse to deliver the inputs in cash deals because they cannot expect a positive profit . Thus, in a cash economy the lack of trust and liquidity prevent many profitable trades from taking place.

In a non-cash economy the deal can go through by choosing the "right" prices for the "sale" and the "goods payment", because of two reasons. First, by introducing a second profitable transaction in the form of the "goods payment" 
the producing firm can buy an inflated input and still make a profit. ${ }^{13}$ Second, the input supplying firm gets a discount on the barter good which allows her to cover the credit enforcement cost. Thus, the non-cash economy helps to maintain output which otherwise would collapse due to imperfect input and credit markets. The imperfections of input and credit markets are reflected in a shift in the terms of trade of barter. Through the inflated price for the "sale" and the price discount on the "goods payment" the deal is actually saved by guarantying both parties a positive profit. The shift in the terms of trade is the mechanism by which the non-cash economy accomplishes to maintain ouput which otherwise would collapse in a cash economy.

\subsection{The Time Pattern of Barter}

How can this story explain the time pattern of demonetization in Russia given in Figure 1? In 1992 firms have accumulated substantial debt among each other due to a refusal of the banking sector to provide credit. Firms turned to other firms for trade credits when bank credit was not available. Accumulated arrears reached a critical level in 1995 at which production was unsustainable due to prohibitively large credit enforcement costs. At this point firms refused to extend further trade credit (in cash) to each other out of the worry of not being paid. Barter then stepped in as the only way to maintain production. At this point barter started to substitute for the non active banking sector as well as for trade credits in cash which explains the explosive increase. Why then has barter started to decline with the financial crisis in $1998 ?$

In order to get to an answer it is useful to compare Russia with Ukraine. Both countries are similar with respect to the time patter of barter (in both countries barter exploded until 1998 and declined thereafter), but they differ with respect to the exchange rate and oil ressources. Russia is an oil exporter, Ukraine is an oil importer. The ruble depreciated by about 50 percent after the August financial crisis, while the hryvnia showed only a modest decline. The strong devaluation of the exchange rate and booming world oil markets have both been argued to

\footnotetext{
${ }^{13}$ The model actually predicts that in equilibrium the hold up problem is "solved" and thus input prices will not be inflated. A look at Table 3 reveals that in $73.6 \%$ of the deals this was actually the case.
} 
have contributed to the vanishing barter economy after 1998. ${ }^{14}$ However, the different behavior of the exchange rates and in the importance of oil in these two countries suggests that some other force must be at work to explain the striking similarity in the time pattern of barter.

Is the virtual economy argument a candidate explanation? To construct an argument for the vanishing barter economy along the lines of the virtual economy hypothesis one has to find a reason why in 1998 the energy producers stopped providing subsidies to the manufacturing sector. Is is because the energy producers had less money available? Or because manufacturing firms suddenly started to create value in 1998? The booming world oil markets and the associated increase in rents of the energy sector should have made it easier rather than more difficult for this sector to transfer value to the rest of the economy. Why then has barter started to decline in 1998? The virtual economy argument does not seem to offer an answer.

\subsection{Out of a Banking Development Trap?}

In order to find an answer for the decline in barter we have to turn to the financial sector. One common feature between Ukraine and Russia that the virtual economy argument does not touch upon is the financial sector. Russia and Ukraine are the transition countries with the lowest level of bank intermediation (see Huang, Marin, Xu 2003). Banks practically did not lend to the real sector and financed the government budget instead. Huang, Marin, Xu (2003) argue that this was due to a banking development trap. Banks are not able to distinguish good credit risk firms from bad ones. They charge interest rates that cover the average credit risk of all borrowing firms. This, in turn, induces low-credit risk firms to turn to barter trade to avoid subsidizing the high credit risk firms. The option for low credit risk firms to raise liquidity through barter trade drives up bank lending rates, since banks expect higher credit risk firms to remain in the pool of borrowing firms. In equilibrium, only high credit risk firms borrow from banks while the low credit risk firms turn to barter. The banking sector looks for high yield government securities in which to invest. The financial sector is separated from the real sector of the economy which hinders banking sector development.

\footnotetext{
${ }^{14}$ see Ahrend, Aukutsionek, and Parilova (2000) and OECD (2000) who make a similar point.
} 
With the collapse of of the treasury bills market after the August financial crisis banks lending behavior changed drastically. They stopped to finance the government budget and have started to lend to firms. The vanished market for governement bonds induced the banks to reallocate their assets to the real sector of the economy. They lowered interest rates to attract borrowers. Lower interest rates made it attractive for some better risk firms to start borrowing from banks rather than to continue to barter trade. This improved the creditworthiness of the pool of borrowers and, in turn, further lowered interest rates and induced more firms to switch from barter to bank loans. This way, the financial crisis of 1998 helped Russia and Ukraine to get out of a banking development trap which explains why barter has dropped (see Huang, Marin, Xu (2003)). 


\section{References}

Ahrend, Rudiger, Sergei Aukutsionek and Sveta Parilova "Russian Industry - Cashless or Hopeless? - Explaining a Decade of Barter", Russian European Centre for Economic Policy, Moscow 2000.

Blanchard, Olivier and Michael Kremer "Disorganization", Quarterly Journal of Economics, 1997, 112, 1091-1126

Calvo, Guillermo A. And Fabrizio Coricelli "Inter-enterprise Arrears in Economies in Transition", in Holzmann Robert et al. (eds.): Output Decline in Eastern Europe, 1995a, Dordrecht: Kluwer Academic Publishers

Calvo, Guillermo A. And Fabrizio Coricelli "Output Collapse in Eastern Europe: The Role of Credit", in M.I. Blejer, Calvo G., Coricelli F. and A. Gelb (eds.): Eastern Europe in Transition: From Recession to Growth? World Bank Discussion Paper 196, World Bank, Washington 1995b

Commander, Simon and Christian Mumssen "Understanding Barter in Russia" European Bank for Reconstruction and Development, 1998, mimeo, London

European Bank for Reconstruction and Development, Transition Report London, 1997 26-27

Gaddy, C.G. And B.W. Ickes "Russia's Virtual Economy", Foreign Affairs 1998, 77(5), 53-67

Huang, Haizhou., Dalia Marin and Chenggang Xu "Financial Crisis, Economic Recovery and Banking Development in Russia and Other FSU Countries", International Monetary Fund Discussion Paper, International Monetary Fund, Washington , 2003

Johnson, Simon, John McMillan and Christopher Woodruff "Contract Enforcement in Transition", Cambridge, San Diego, mimeo, 1999

MARIN, DAlia "Monetary Policy Does not Work in Russia's Barter Economy - German Banking as a Solution?" Economic Systems, March 2000

Marin, Dalia, Kaufmann Daniel and Bogdan Gorochowskij "Barter in Transition Economies: Competing Explanations Confront Ukrainian Data", in: Seabright, Paul (Ed.) The Vanishing Rouble, Cambridge University Press, Cambridge 2000

Marin, Dalia and Monika Schnitzer "Contracts in Trade and Transition: The Resurgence of Barter", Cambridge, MIT Press, 2002

Marin, Dalia And Monika Schnitzer "Disorganization and Financial Collapse", European Economic Review, 2003, fothcoming 
Organisation for Economic Cooperation and Development OECD Economic Surveys: Russian Federation 1997, Paris 1997-1998

Organisation for Economic Cooperation and Development OECD Economic Surveys: Russian Federation 2000, Paris 1999-2000

Russian Economic Barometer Survey of Industrial Firms, Institute for World Economy and International Relations, Moscow, 1997 